\title{
Proposal and Description of ATCC 13683 and ATCC 12102 as Neotype Strains of Actinomyces bovis Harz 1877 and Actinomyces israelii (Kruse) Lachner-Sandoval 1898, Respectively
}

\author{
JOHN M. SLACK AND MARY A. GERENCSER \\ Department of Microbiology, Medical Center, West Virginia University, Morgantown, West Virginia 26506
}

Actinomyces bovis ATCC 13683 and A. israelii ATCC 12102 are described, and they are here designated as the neotype strains of these two species.

In 1877 Harz (1) applied the name Actinomyces bovis to an organism observed in granules present in the cheese-like pulp from "jaw sarcoma" of cattle. This was followed by a more complete description in 1879 (4). The generic name was conserved, and $A$. bovis was designated as the type species by Winslow et al. in 1920 (15). This was supported by Lessel (8) in his extensive review, and $A$. bovis has been included in each edition of Bergey's Manual, including the eighth (12), but a type strain has not been proposed. Actinomyces israelii was first isolated by Bujwid (2) in 1889 and was described in considerable detail by Wolff and Israel in 1891 (16). Kruse (6) applied the name Streptothrix israeli to the organism isolated by Wolff and Israel, but the generic name Streptothrix was not valid as it had been preempted by Corda (3) for a true fungus designated as Streptothrix fuca. In 1898 Lachner-Sandoval (7) completed a dissertation on the "ray fungi" which was primarily a literature review and discussion and applied the name Actinomyces israelii Kruse to the isolates of Wolff and Israel.

As type strains have not been designated for $A$. bovis and $A$. israelii and because none of the strains on which the original descriptions of these organisms were based is extant, ATCC 13683 and ATCC 12102 are here designated as the neotype strains of $A$. bovis and A. israelii, respectively.

For several years, the members of the Subgroup on the Taxonomy of the Microaerophilic Actinomycetes (11) participated in a cooperative study of selected strains of Actinomyces, Arachnia, Rothia, and Bacterionema. The strains chosen for each species were, in most cases, the type, cotype, or neotype strains. Two species of the genus Actinomyces, A. bovis and $A$. israelii, did not have designated type strains, and so $A$. bovis ATCC 13683 and $A$. israelii ATCC 12102 were chosen for study. The following descriptions of these strains are based on the subgroup study, on additional studies in our laboratory, and from reports in the literature.

Strains. A. bovis strain ATCC 13683 was isolated from bovine lumpy jaw by Leo Pine and given the number P-1. It has also been designated as Pine 1, CDC X521, and WVU 116. This strain was described by Pine et al. (10) in 1960 after being deposited in the ATCC on 20 November 1959.

A. israelii strain ATCC 12102 was isolated by Luther Thompson from a human brain abscess at the Mayo Clinic in 1948 and given the number 277. It has also been designated as H277, CDC X523, CDC W855, and WVU 46. This culture was deposited in the ATCC by Arden Howell, Jr., on 16 March 1955.

Methods. The methods used for characterizing the two strains have been described by Slack (11), Slack and Gerencser (13), and Slack et al. (14).

\section{Actinomyces bovis Harz, ATCC 13683}

Morphology. Gram-positive rods in diphtheroidal arrangements; $\mathrm{V}, \mathrm{Y}$, and $\mathrm{T}$ forms seen; moderate number of long filaments with branching in most smears; clubbing common.

Microcolony morphology. Circular, flat, granular to smooth; may have an optically dense, granular center; no filaments at the edge of the colony. In the culture studied by the subgroup, occasional small filamentous colonies (spider colonies) were seen on 18- to 24 -hold plates.

Mature colony morphology. Varies from 0.5 to $1.0 \mathrm{~mm}$ in size; low convex to convex; circular; smooth or granular surface; entire edge; opaque; white; soft. Colonies on brain heart infusion agar and blood agar are similar; not hemolytic on blood agar.

DNA. The guanine plus cytosine $(\mathrm{G}+\mathrm{C})$ content of the deoxyribonucleic acid (DNA) was found to be $63 \mathrm{~mol} \%$ by Johnson and Cummins (5), while Hammond (13) reported a value of 53.5 . 
TABLE 1. Oxygen requirements and biochemical reactions of Atinomyces bovis and A. israelii ${ }^{a}$

\begin{tabular}{|c|c|c|c|c|c|}
\hline Test & $\begin{array}{c}\text { A. bovis ATCC } \\
13683\end{array}$ & $\begin{array}{c}\text { A. israelii } \\
\text { ATCC } 12102\end{array}$ & Test & $\begin{array}{c}\text { A. bovis } \\
\text { ATCC } \\
13683\end{array}$ & $\begin{array}{c}\text { A. israelii } \\
\text { ATCC } \\
12102\end{array}$ \\
\hline \multirow{6}{*}{$\begin{array}{l}\text { Oxygen requirements } \\
\text { Aerobic } \\
\text { Aerobic }+\mathrm{CO}_{2} \\
\text { Anaerobic } \\
\text { Anaerobic }+\mathrm{CO}_{2}\end{array}$} & \multirow{6}{*}{$\begin{array}{r}+ \\
+ \text { to } 2+ \\
3+ \\
3+\end{array}$} & \multirow{6}{*}{$\begin{array}{c}0 \text { to }+ \\
+ \text { to } 2+ \\
3+ \\
3+\end{array}$} & Fructose & A & A \\
\hline & & & Galactose & A & - \\
\hline & & & Glucose & A & $\mathbf{A}$ \\
\hline & & & Glycerol & - & - \\
\hline & & & Glycogen & A & - \\
\hline & & & Inositol & A & $\mathbf{a}$ \\
\hline Catalase & - & - & Inulin & - & - \\
\hline Indole & - & - & Lactose & A & A \\
\hline Nitrate reduction & - & + & Maltose & A & A \\
\hline Methyl red & + & - & Mannose & $\mathbf{a}$ & - \\
\hline Voges-Proskauer & - & - & Mannitol & - & - \\
\hline Hydrogen sulfide & & & Melezitose & - & - \\
\hline (B)HIA & - & - & Melibiose & - & $\mathbf{A}$ \\
\hline TSI & + & + & Raffinose & - & A \\
\hline Litmus milk & AR & NC & Rhamnose & - & - \\
\hline Gelatin liquefaction & - & - & Ribose & - & $\mathbf{A}$ \\
\hline Starch hydrolysis & + & $\pm^{c}$ & Salicin & - & $\mathrm{A}$ \\
\hline Esculin hydrolysis & + & + & Starch & A & - \\
\hline \multirow[t]{2}{*}{ Urea } & \multirow[t]{2}{*}{ NT } & \multirow[t]{2}{*}{-} & Sorbitol & - & - \\
\hline & & & Sucrose & A & $\mathbf{A}$ \\
\hline Adonitol $^{c}$ & - & - & Trehalose & - & $\mathrm{A}$ \\
\hline Arabinose & - & $-d$ & Xylose & - & $\mathrm{A}$ \\
\hline Cellobiose & - & A & & & \\
\hline Dextrin & A & $\mathrm{a}$ & Serotype & 1 & 1 \\
\hline Dulcitol & - & - & & & \\
\hline Erythritol & - & - & & & \\
\hline
\end{tabular}

a Abbreviations: -, negative; +, positive; \pm , partial hydrolysis; AR, acid reduced; NC, no change; NT, not tested; $A$, acid in 7 days; a, acid in 14 days.

${ }^{b}$ Oxygen requirements: 0 , no growth; + , slight growth; $2+$, moderate growth; $3+$, good growth.

$c$ Tests done in actinomyces fermentation base (BBL).

${ }^{d}$ Acid from arabinose when tested in thioglycolate medium fermentation base (13).

Cell wall composition. The major amino acids in the cell wall are alanine, glutamic acid, lysine and aspartic acid. The major sugars are rhamnose, fucose (trace), deoxytalose, and fast deoxyhexose (12).

Fermentation end products. The major end products of glucose fermentation are acetic, formic, and succinic acids (12).

Oxygen requirements and biochemical reactions. For oxygen requirements and biochemical reactions, see Table 1.

\section{Actinomyces israelii (Kruse) \\ Lachner-Sandoval, ATCC 12102}

Morphology. Gram-positive rods and filaments; $\mathrm{Y}$ and $\mathrm{V}$ forms; swollen and clubbed ends are seen; filaments exhibit branching.

Microcolony morphology. Small filamentous colonies with little or no distinct center. These are typical of the so-called "spider colony."

Mature colony morphology. This strain shows several varieties of rough colony types in repeated platings and may show more than one type on a single plate. Colonies are 0.5 to $2.0 \mathrm{~mm}$ in diameter (usually about $1.0 \mathrm{~mm}$ ); circular to irregular; convex to pulvinate; surface knobby, producing molar-tooth or breadcrumb colonies; may have a deep central depression producing "raspberry-like" colonies; edges undulate; white; shiny; soft.

DNA. The $\mathrm{G}+\mathrm{C}$ content of the DNA has been reported as both 60 (12) and $63 \mathrm{~mol} \%$ (13).

Cell wall composition. The major amino acids are alanine, lysine, glutamic acid, and ornithine. The only major sugar is galactose (12).

Fermentation end products. The end products of glucose fermentation are formic, acetic, lactic, and succinic acids (9).

Oxygen requirements and biochemical reactions. For oxygen requirements and biochemical reactions, see Table 1.

\section{LITERATURE CITED}

1. Bollinger, O. 1877. Über eine neu Pilzkrankheit beim Rinde. Zentralbl. Med. Wiss. 15:481-485.

2. Bujwid, D. 1889. Úber die Reinkultur des Actinomyces. 
Zentralbl. Bakteriol. Parasitenk. Infektionskr. 6:630633.

3. Corda, A. C. J. 1839. Pracht-Flora Europaeiscker Schimmelbildungen. Gerhard Fleischer, Leipzig.

4. Harz, C. O. 1879. Actinomyces bovis ein neuer Schimmel in dem Geweben des Rindes. Jahrebericht der K. Central-Thieraznei Schule in München für 18771878. 5:125-140.

5. Johnson, J. L., and C. S. Cummins. 1972. Cell wall composition and deoxyribonucleic acid similarities among the anaerobic coryneforms, classical propionibacteria and strains of Arachnia propionica. J. Bacteriol. 109:1047-1066.

6. Kruise, W. 1896. Systematik der Streptothricheen und Bakterien. C. Die Mikroorganismen, Bd. 2, p. 48-66. C. Flugge, Leipzig.

7. Lachner-Sandoval, V. 1898. Uber Strahlenpilze. Inaugural-Dissertation Strassburg. Universitäts Buchdruckerei von Carl Georgi, Bonn.

8. Lessel, E. F. 1960. The nomenclatural status of the generic names of the Actinomycetales. Int. Bull. Bacteriol. Nomen. Taxon. Suppl. 10:87-192.

9. Li, Y.-Y. F., and L. K. Georg. 1968. Differentiation of Actinomyces propionicus from Actinomyces israelii and Actinomyces naeslundii by gas chromatography. Can. J. Microbiol. 14:749-753.
10. Pine, L., A. Howell, and S. J. Watson. 1960. Studies of the morphological, physiological and biochemical characters of Actinomyces bovis. J. Gen. Microbiol. 23:403-424.

11. Slack, J. M. 1968. Subgroup on taxonomy of microaerophilic actinomycetes. Int. J. Syst. Bacteriol. 18:253-262.

12. Slack, J. M. 1974. Family Actinomycetaceae and genus Actinomyces, p. 659-667. In R. E. Buchanan and N. E. Gibbons (ed.), Bergey's manual of determinative bacteriology, 8 th ed. Williams and Wilkins Co., Baltimore.

13. Slack, J. M., and M. A. Gerencser. 1975. Actinomyces, filamentous bacteria: biology and pathogenicity. Burgess Publishing Co., Minneapolis.

14. Slack, J. M., S. Landfried, and M. A. Gerencser. 1969. Morphological, biochemical and serological studies on 64 strains of Actinomyces israelii. J. Bacteriol. 97:873-884.

15. Winslow, C. E. A., J. Broadhurst, R. E. Buchanan, C. Krummwiede, L. A. Rogers, and G. H. Smith. 1920. The families and genera of bacteria. J. Bacteriol. 5:191-229.

16. Wolff, M., and J. Israel. 1891. Ueber Reinultur des Actinomyces und seine Uebertragbarkeit auf Tiere. Arch. Pathol. Anat. Physiol. Klin. Med. 126:11-59. 